Water Policy 11 (2009) 569-581

\title{
Virtual water trade: a realistic policy option for the countries of the Volta Basin in West Africa?
}

\author{
Eva Youkhana* and Wolfram Laube \\ Center for Development Research, Walter-Flex-Str. 3, 53113 Bonn, Germany \\ *Corresponding author. Fax: 0049-228-731972. E-mail: eva.youkhana@uni-bonn.de
}

\begin{abstract}
Trade in virtual water, the substitution of the use of scarce water resources for agricultural production by importing food from water-rich countries has been said to be a potential solution to water crises and water conflicts throughout water-stressed regions worldwide. While trade in foodstuffs may have helped to alleviate water stress in parts of the Middle East and Northern Africa and provides an efficient response to the periodic drought occurrences, it has to be doubted whether virtual water trade is a water governance option that can be applied in many countries of the South. As examples from the West African Volta River Basin suggest, cultural values focussing on agricultural and livestock production, socio-economic factors such as a low level of education and a strong dependency of livelihoods on subsistence agriculture, weak governments that are unable to trigger and finance large-scale reform processes, as well as dysfunctional and unfair market systems, largely limit the widespread application of virtual water trade.
\end{abstract}

Keywords: Socio-political and cultural values of food production; Virtual water trade; Volta Basin

\section{Introduction}

Virtual water trade has been portrayed as an instrument which could have the potential to alleviate water stress, avoid resource conflicts and reduce poverty and hunger in (semi-) arid regions world wide. Proponents of the virtual water approach, mostly using examples from the Middle East and Northern Africa (Allan, 1995, 2001) as well as from Southern Africa (Turton, 2000), have shown that waterstressed countries from these regions have the potential to reduce the pressure on their scarce water resources. Thus, water intensive food production could be substituted by the import of foodstuffs from water-rich countries purchased on the world market (Chapagain et al., 2005).

While we agree that trade in foodstuffs has long been used to bridge differences in resource endowment on various scales, and has provided the means to alleviate the consequences of short- and medium-term water scarcity such as droughts, we nevertheless believe that the debate over the possible

doi: 10.2166/wp.2009.087

(C) IWA Publishing 2009 
merits of virtual water trade suffers from some substantial flaws. Some of the flaws of the approach have been pointed out before. (Merrett, 2003a: 105) has convincingly shown that the term 'virtual water' is rather metaphorical and masks that in fact real water used for food production is the subject matter of the virtual water trade debate. The application of the virtual water trade approach as a water management tool and driver of (inter-) national water policies is questionable. The terminology, as well as the macrolevel analysis of hydrological, economic and agricultural data that is usually applied by the proponents of the concept, turns a blind eye on important cultural, socio-economic and political features that underlie and rule agricultural production patterns, water use and market exchanges at various levels.

This paper aims to show some of the analytical faults inherent in the virtual water approach and wants to make implicit some of the limits for the implementation of virtual water trade as a political strategy. In order to do so, this paper will take a closer look at the West African Volta Basin. After a description of the main features of the Volta Basins hydrology, water availability and water stress, especially with regard to the two main riparian countries Ghana and Burkina Faso, some of the main questions that the virtual water trade raises as analytical tool as well as a water policy instrument will be proved. The focus will be on the cultural, socio-economic and political viability of the substitution of food production in (semi-) arid parts of the Basin by the importation of food stuffs from water-rich parts of the Basin or global markets.

\section{Water availability and scarcity in the Volta Basin}

The Volta Basin is located in West Africa and covers around $400,000 \mathrm{~km}^{2}$ of the sub-humid and semiarid savannah zone. The basin encompasses the majority of Ghana's territory (70\% of land area) as well as that of Burkina Faso (63\%), and lesser proportions of Togo, Benin, Mali and Cote d'Ivoire, respectively. The climate is influenced by the movement of the Inter-Tropical Convergence Zone (ITCZ). The average rainfall lies around $1,000 \mathrm{~mm} / \mathrm{yr}$, with a strong north-south gradient and regional and temporal variability (Rodgers et al., 2006). Predominantly in the northern parts of the Basin, in Northern Ghana and Burkina Faso, precipitation is as low as $300-700 \mathrm{~mm} / \mathrm{yr}$. While this seems still to be high, it has to be stated that most of this rain is concentrated during the rainy season, and during the rest of the year there are hardly any rains at all. Currently, climatic patterns within the Basin are changing as temperatures are rising, the rainy season is shifting and shortening, and rains become less reliable (Kranjac-Berisavljevic et al., 1999: 8; Wiggins, 1999: 10). Unpredictable and unreliable precipitation makes rainfed agriculture a risky undertaking throughout much of the Basin (Rodgers et al., 2006). Mean annual temperatures are around $30^{\circ} \mathrm{C}$ and humidity varies between $90 \%$ in coastal areas to below $20 \%$ in the north during the harmattan, a dry and dusty wind that blows from the Sahara to the Gulf of Guinea between November and March, and during the dry season (MoWH, 1998; Andah \& Gichuki, 2003). Climate and land cover changes as a consequence of global climate change patterns and the increasing population density in the region led to significant changes in rainfall characteristics. In the past, the grave water deficiency during extensive droughts had ruinous consequences for the population concerned, and partially caused irreversible ecological damage (Kunstmann \& Jung, 2003). The large rainfall variability turns West Africa into a region with permanent climatic problems and frequent water stress. While the Volta Basin, especially in the northern parts of Ghana and in Burkina Faso, is commonly perceived as a water-scarce environment, analyses by proponents of the virtual water paradigm seem to have a different view on this issue. In their seminal publication 'Virtual Water Trade', 
which attempts a quantification of global virtual water flows in relation to crop trade, Hoekstra \& Hung (2002: 55-56) portray Burkina Faso and Ghana as water-rich countries with a water scarcity of 2.4 and $0.6 \%$ respectively ${ }^{1}$. This perception derives from the reliance on macro-level data sets, which cover the seasonal and erratic nature of water availability. Although the data create the impression of water abundance, this is rather a myth. Runoff is dependent on rainfall, which has been shown to be prone to variations, and small variations in precipitation result in large changes in the amount of runoff. Those fluctuations in runoff frequently cause agricultural losses and threaten the hydropower production in Ghana (Van Edig, 2002: 77), population growth and economic development leading to a rising water demand, as well as to already existing regional and sectoral water shortages, uncontrolled pollution and the inefficient management of drinking water supplies and the accompanying threats of local, sectoral or international conflicts are some of the main features of the Volta Basin (Laube \& van de Giesen, 2006).

Current water stress is going to increase significantly as deteriorating climatic and hydrological conditions and an ever increasing domestic, industrial and especially agricultural demand for water put rising pressure on the Basin's water resources ${ }^{2}$. Therefore, the Volta Basin, especially the northern parts of Ghana and Burkina Faso, is an area that could qualify for the implementation of virtual water trade policies.

In the following section, we want to show what impact virtual water trade could have on the agricultural production patterns of the Basin, which constraints this policy option might face and what problems it could create. To do this, we will first have to have a short look at the prevalent agricultural production patterns of the Volta Basin.

\section{Subsistence agriculture, cash-crop production, livestock and rural livelihoods in the Volta Basin}

By African standards, the Volta Basin is densely settled with Ghana, at 90 inhabitants per $\mathrm{km}^{2}$, possessing roughly three times the mean population density of Sub-Saharan Africa (SSA). Basin inhabitants are overwhelmingly rural. Agriculture is the most important economic factor, followed by services (in Burkina Faso even more important than agriculture) and industry (see Table 1).

Today $70 \%$ (in Ghana) to $90 \%$ (in Burkina Faso) of the population in the Volta Basin depends on subsistence and cash crop farming. As in many parts of Africa, agricultural productivity is low in comparison to other regions in the world (World Bank Group, 2004). Nevertheless, in spite of climatic uncertainties, agriculture is a driving force of economic growth and is actively promoted by both governments. While the secondary and tertiary sectors are becoming more important, especially in Ghana, this development is largely limited to the south of the country where some degree of industrial development is taking place and most of the raw materials such as gold, diamonds or bauxite are mined.

\footnotetext{
${ }^{1}$ National water scarcity is the function of annual renewable water resources and annual groundwater and surface water use. It is expressed in percentages. Low percentages characterize water-rich nation states, while high percentages characterize waterpoor nation states (Hoekstra \& Hung, 2002: 16).

${ }^{2}$ In Ghana, for instance, the agricultural water demand, mostly for irrigation, is said to increase sevenfold from

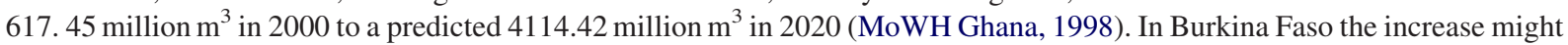
be even more significant, as more and more farmers are relying on irrigated agriculture to engage in cash crop production and alleviate the detrimental impacts of erratic and changing climatic conditions.
} 
Table 1. World Development Index for Ghana and Burkina Faso (2004); (Source: World Bank Group, 2004).

\begin{tabular}{lll}
\hline Country & Development index & $\%$ of GDP in 2004 \\
\hline Burkina Faso & Agriculture & 30.79 \\
& Industry & 19.86 \\
\multirow{3}{*}{ Ghana } & Services, etc. & 49.35 \\
& Agriculture & 37.91 \\
& Industry & 24.73 \\
\hline
\end{tabular}

Apart from production of foodstuffs for local national and regional markets, both countries depend largely on the production of cash-crops for international markets. In Ghana, cocoa farming accounts for $30-40 \%$ of the export revenues and contributes $13 \%$ of the national GDP. Cocoa farming is dominated by small-scale farmers and roughly 1.5 million cocoa farmers produce more than 700,000 tons of cocoa annually (International Cocoa Organization (ICCO), 2005). Apart from cocoa, palm nuts, rubber and pineapples are agricultural products which are sold at global markets. These cash crops are all grown in the southern, tropical parts of the country where water is abundant. The clear focus on cash crop production led to a situation in which Ghana was already dependent on food imports, mainly in the form of rice and wheat flour, in colonial times (Agbodeka, 1992). Food imports have since posed a serious threat to the Ghanaian economy as they have heavily burdened the foreign exchange balance of the country. Various Ghanaian governments, including the colonial administration of the Gold Coast Colony, have therefore tried to promote an increase in food production (Konings, 1986). As the country depends heavily (apart from the export of gold, timber and minerals) on the revenues derived from the sale of agricultural cash crops, those programs mainly focussed on the intensification of food crop production in the semi-arid northern parts of the country where local peasants engage mostly in subsistence agriculture and frequently supplement their livelihoods through labour migration (Kasanga \& Avis, 1988). The disappropriation of land, the forceful introduction of new crops and agricultural techniques, as well as the appropriation of credits, subsidees as well as agricultural inputs by local and regional elites, led to the withdrawal of many peasants who only slowly began to adopt the innovations (Bates, 1981; Konings, 1986). When agricultural subsidies were cut, most commercial farmers abandoned farming as they were only thriving on the capture of public resources. Nevertheless, since the mid-1990s many more farmers have started to supplement increasingly insecure rain-fed agriculture through the irrigated cultivation of (mostly) vegetables and rice, which are sold at national markets. Irrigated agriculture enables them to farm during the long dry season and to avoid labour migration to the south.

In Burkina Faso cotton production has a similar economic importance as cocoa production in Ghana. It accounts for approximately $30 \%$ of the total export earnings and $60 \%$ of the agricultural exports. The cotton industry has played a key role in building up the country's infrastructure and social services (Caritas \& CIDSE, 2004). Cocoa as well as cotton production are adjusted to the climatic conditions of the region but face major challenges. Due to adjustment programs both in Ghana and in Burkina Faso, market reforms, implemented from the early 1980s, have had an impact on production conditions of small-scale farmers. While cotton and cocoa growing has always been a family affair, the liberalization and privatization of these sectors, as well as reduced subsidies on inputs, has made it more difficult for small-scale farmers to compete with emerging private companies.

Apart from cotton, vegetable farming, and especially the production of tomato for the Ghanaian market, has become increasingly important. Competing with farmers from Ghana's north, many 
Burkinabe farmers are taking advantage of the ever-increasing number of mostly small dams to produce tomatoes during the dry season. At this time of the year, rains in southern Ghana render tomato production impossible and both Northern Ghana and Burkina Faso are using this seasonal advantage to profit from the large demand in the south of the Basin.

As can be seen, it is especially in the water-scarce northern parts of the Volta Basin that agricultural production, particularly irrigated dry-season farming, plays a crucial role in the generation of overwhelmingly rural livelihoods, through subsistence agriculture and the production of cash crops for regional and global markets. As climatic patterns are changing and rain-fed agriculture is becoming increasingly risky, water-intensive irrigated agriculture, both promoted by national governments, donors and NGOs, and expanded through farmers' initiative, are becoming more and more important (Rodgers et al., 2006).

Apart from the cultivation of crops, the production of livestock is an important additional source of rural livelihoods in the northern parts of the Basin. The prevalence of tsetse flies and the spread of tryptomiasis throughout the tropical part of the Basin have kept the level of animal production very low in the south. Therefore, the northern parts of the Basin enjoy a comparative advantage for the production of livestock, and traditionally livestock is imported from the semi-arid and arid parts of the Basin. Burkina Faso in particular and, to a lesser extent, Northern Ghana provide a large share of the cattle, sheep and goat brought to southern markets and slaughterhouses. Although the export of livestock in Burkina Faso has seen a sharp decline in recent years (due to the civil war in the Ivory Coast which used to be the main importer of Burkinabe livestock), livestock exports to Ghana are nevertheless important for many farmers and herders in Burkina Faso (Table 2).

Like cash crop production, the livestock sector is mainly dominated by small-scale producers who rely on livestock as an additional income source, as a storage of wealth and as a method of alleviating the impact of droughts. Livestock production is dominated by a specialised semi-nomadic ethnic group, the Fulani or Peul, who almost entirely depend on the keeping of livestock which they either own or keep in contract for sedentary owners in farming communities. Livestock or the production of meat, is known as a water intensive agricultural activity. One argument of the virtual water trade's advocates refers to the huge amount of water meat needs to be produced, and it is therefore argued that meat should not be exported from water-scarce environments to water-rich environments (Chapagain \& Hoekstra, 2004). While a look at gross statistics may support this view, it still remains true that pastoralism is one of the few economic activities that is highly adapted to (semi-) arid environments. In Africa and beyond, pastoralists are usually found in dry savannah areas which do not easily lend themselves towards farming. An intimate knowledge of the particular environment and a large degree of mobility has made pastoralism a highly successful coping strategy in water scarce environment, although huge amounts of water may be needed to produce one kilo of meat. This fact is easily glossed over, when the focus is only on macro statistics and numbers pointing at water requirements for production.

Table 2. Livestock exports from Burkina Faso, 1997-2004. (Source: Faostat, 2006).

\begin{tabular}{llrrrrrrrr}
\hline Type & Exports & 1997 & 1998 & 1999 & 2000 & 2001 & 2002 & 2003 & 2004 \\
\hline Cattle & Heads(1000) & 179 & 135 & 134 & 144 & 242 & 204 & 39 & 19 \\
& Value (Million US\$) & 14 & 14 & 13 & 8 & 17 & 15 & 5 & 3 \\
Goats & Heads(1000) & 87 & 71 & 123 & 45 & 101 & 61 & 34 & 10 \\
& Value (Million US\$) & 2 & 2 & 1 & 0.8 & 1 & 0.5 & 0.6 & 0.1 \\
Sheep & Heads(1000) & 224 & 130 & 189 & 97 & 195 & 131 & 35 & 47 \\
& Value (Million US\$) & 4 & 5 & 5 & 4 & 3 & 3 & 0.5 & 0.9 \\
\hline
\end{tabular}




\section{Challenges for the use of virtual water trade as a policy option in the Volta Basin}

Virtual water trade is not likely to be of major importance for the governance of water resources or the solution of water scarcity and water-related conflicts in the West African Volta Basin. Apart from for the alleviation of the detrimental effects of droughts, which have occasionally already necessitated large imports of foodstuffs (mostly in the form of food aid), there is no reason to believe that any major reduction of agricultural production, to be replaced by the import of foodstuffs, will be instigated within the (semi-) arid and increasingly water-scarce northern parts of the Volta Basin. There are ample cultural, socio-economic and political impediments that would preclude virtual water trade from becoming a viable water governance option in the foreseeable future. In the following section, we outline the major factors that led to this conclusion and discuss relevant policy aspects for the region.

\subsection{Cultural constraints}

Economic activities and the patterns of production are not only means to produce foodstuffs, make a living and accrue wealth but are, especially in the context of the Volta Basin and also in many other rather 'traditional' societies around the globe, deeply embedded in the cultural and religious systems of those societies. Farmers do not only farm and rear livestock in order to secure meagre livelihoods and to meet their nutritional demands but also do so because farming is a deeply rooted part of their sociocultural living environment and belief system, providing them with the means to allow them to engage in important social and spiritual activities, and granting them access to status and social acclaim. In Northern Ghana for instance, many farmers, despite or because of the experience of labour migration to the south, express a deep affiliation to their agricultural activities. They are still able to remain as relatively independent producers, who create their identity around farming and take pride in their economic achievements, however small they are. The production and rearing of especially millet, fowl and cattle provides farmers with the means to perform fundamental rituals for example to engage in marriage by using the these products as dowry or as goods for reciprocal activities. Possession of larger numbers of cattle goes along with high social status and hardworking and successful farmers are held in high esteem. While often deprived of access to (higher) education and alternative forms of social mobility, farming and livestock rearing provides non-alienated means to lead to spiritual security and social embeddedness. Furthermore, locally produced 'traditional' foodstuffs are often preferred for consumption as they are perceived to be more healthy and tasty.

Another example in case are the semi-nomadic Fulani, who have traditionally adopted their lifestyle to the needs of livestock rearing in a (semi-) arid environment, in which access to pasture is difficult and transhumance is highly adapted to the specific local climatic patterns. At least parts of the Fulanis' social and spiritual life are largely organized around the 'traditional' schedule of their semi-nomadic lifestyle. Cattle rearing remains an indespensable part of their identity as well as spiritual and social activities.

Traditional forms of livestock husbandry and agriculture illustrate not only the cultural and social dimension of economic activities in the region but also show how different ethnic groups have adapted themselves to water scarce environments.

While cultural values and patterns of production are changing and parts of the population disengage or are forced to disengage from their traditional economic production patterns and lifestyles, as they for instance sedentarize, engage in labour or migrate to the larger cities, the resilience of 'traditional' lifestyles, identities and cultural and religious patterns should not be underestimated. Any external 
initiatives that would aim at the abolition or limitation of farming would therefore certainly be met with fierce opposition or, as effective, strategies of evasion (Scott, 1985). The ability of local populations, especially peasants, to evade external policies has been hotly debatted throughout the 1970s and and 1980s and the lessons learned should not be forgotten (see for instance Lemarchand, 1989).

\subsection{Socio-economic constraints, dysfunctional markets and the detrimental conditions of global trade}

While a change of agricultural production patterns may run counter to cultural and religious systems and therefore be met with resistance, it remains completely unclear how such large economic changes should be achieved from a purely economic perspective. As has been shown above, the population in the (semi)-arid parts of the Volta Basins is largely (up to $90 \%$ of the economically active population) engaged in agriculture. It remains entirely unclear how these people are supposed to make their living if not as farmers and pastoralists. Economic transformation, moving away from a reliance on agriculture and the exploitation of natural resources, has been the objective of an almost endless number of development initiatives and adjustment programs throughout many countries of the South. While some countries, mainly in South East Asia or in Latin America, may provide success stories, most of the countries of the South are, despite major efforts to the reverse, still characterized by huge agricultural populations and predominantly agricultural production patterns. In these countries, food production is likely to depend further on local (subsistence) production (Applegren, 2004). Looking at the Volta Basin, any other expectation seems to be completely unrealistic. Given the rural character of large parts of the population, a low degree of educational and vocational achievement, and the rather slow development of alternative economic activities in the secondary and tertiary sectors of the economy, water governance based on virtual water trade is entirely unrealistic. Both Burkina Faso and Ghana lack the economic resources and human capacities to engage in large-scale industrialization or a large expansion of the service sector. While Burkina Faso is, according to human development indicators, amongst the poorest countries worldwide (UNDP, 2003), Ghana, which is relatively well endowed with natural resources, is nevertheless rated as a Highly Indebted Poor Country (HIPC) and has just received, like Burkina Faso, a multilateral debt reduction by major lending countries (IMF Fact Sheet, 2006). Additionally, the international financial and economic regime, imposed by the Bretton-Woods institutions such as the World Bank and the International Monetary Fund and other international donors, preclude any large investment initiatives

by the state. As major (international) private investment is small at best, no major economic development outside the agricultural sector is to be expected in the near future. Looking at the country's development visions (Government of Ghana, 1995), agriculture is seen as an integral part, or even a driving force, of future economic developments. The expansion of agricultural and hydraulic infrastructure is high on the development agenda since economic alternatives apart from agriculture are largely missing. Given the fact that in Ghana, for instance, unemployment has reached $20 \%$, the promotion of food imports in the framework of virtual water trade would throw further parts of the population into extreme poverty.

Apart from a lack of capital and human resources, it is the unequal terms of trade which frequently render initiatives towards diversification of the Basin's economies impossible. While import duties for raw materials in the North remain as low as the world market prices for these goods (which have themselves declined during the last 30 years, e.g. cocoa which has dropped by 30\%), the industrialized countries protect their markets from imports of agricultural products and processed good (Bradford, 2003). This largely inhibits the development of a processing industry in the Basin and negatively affects local markets, as does (perhaps even more so) the high level of subsidies for agricultural products and 
their processing in especially the EU and the US. Large imports of rice and wheat as well as tomato paste at extremely low prices have rendered most local initiatives for the construction of processing plants unprofitable (Christian Aid, 2002a, b). Furthermore, agricultural subsidies and trade barriers cut the possible profits from agricultural exports. Burkina Faso has been trying for a long time to achieve better market access for its cotton and livestock products in the US and EU (WTO, 2001). The existing trade barriers have rendered specialization in cotton as a climatically-adapted agricultural product dangerous for small-scale cotton producers. As long as, under current terms-of-trade, the production of alternative products such as cotton does not provide secure livelihoods to the producers, it is highly questionable how far the substitution of food and livestock production with food imports would be viable.

But it is not only international markets that are problematic. The markets within the Basin are partly dysfunctional. Trade is impeded by innumerable checkpoints, which do not just exist between but also within states, where police and other customs officers charge legal but also illegal customs. Corruption and institutional disintegration largely increase the transaction costs of trade. Many markets within the Basin are controlled by highly organized cartels that often act with political backing. In Ghana, for instance, so-called market queens, female entrepreneurs who largely control the trade in foodstuffs from rural areas into the urban centres are frequently able to manipulate producer as well as consumer prices. They often act with political backing, as through their control of prices they are effectively able to steer public opinion about, for example, the imposition of new agricultural policies.

The Economic Community of West African States (ECOWAS), to which all riparian states of the Volta Basin belong to, demonstrates the constraints in implementing cross-national terms of trade. ECOWAS was established in 1975 to strengthen cooperation and market integration and to create an economic and monetary union for promoting economic growth and development in West Africa. Since the onset, ECOWAS faces many problems in the process of integrating West Africa economically, including political instability and lack of 'good governance' that has plagued many member countries, the insufficient diversification of national economies, the absence of reliable infrastructure, and the multiplicity of organizations for regional integration with the same objectives (EIA, 2003). The African Development Bank stated in 2004, that just $10 \%$ of West African trade takes place within the member states (Kempf, 2005). This frustrating trade balance can be compared to the situation in the Volta Basin. Thus, in 2004 just 4.7\% of Burkina Faso exports went to Ghana; according to the World Fact Book (2006) Burkina Faso is not considered a relevant trading partner for Ghana and is not even mentioned as export partner.

However, any attempt to introduce virtual water trade as a strategic instrument to optimize water use in a cross-boundary region like the Volta Basin relies heavily on a comprehensive and functional institutional set-up. In the Volta Basin there is presently no such overlapping institution with market supervision functions in place.

\subsection{Political and institutional constraints}

Apart from cultural and economic constraints it is the specific political and institutional situation in many countries of the South that precludes the implementation of the virtual water approach as an effective means of water governance. In many countries, the state is not only financially incapable of triggering large scale economic transformations but also lacks the political authority to embark on controversial policies that would affect large parts of the population. In Burkina Faso as well as in Ghana, the various levels of governance, the state, the region and the districts, have only a limited ability to control the activities of the population. State laws and regulations are only one of a number of 
traditional, customary, religious and local institutions that may become the framework of reference for human agency (von Benda-Beckmann \& van der Velde, 1992). The state frequently lacks the resources, power, local legitimacy and even the will to impose widespread compliance to its institutions. It reigns through alliances with 'traditional' authorities, religious leaders and local 'big men' who allow for a certain degree of control of the flow of resources, enabling the government to stay in power, but equally are able to locally adapt, modify or even ignore official institutions (Berry, 1993). Governance, on different levels, is characterised by a significant degree of political patronage, nepotism and outright corruption which again render the implementation of policies ineffective and therefore allow the societal actors to have a strong impact on the policies of a rather weak state (Migdal, 1988). Particularly in the largely rural states of the Volta basin, governmental policies that have a detrimental effect on the large number of farmers are usually avoided.

The advocates of virtual water trade overestimate the financial and managerial capacities of governments and administrations, and turn a blind eye on economic path-dependency and the dysfunctionality and inherent inequality of many local, national, regional and global markets. Governments lack the incentive and often also the political leverage to engage in large restructuring programmes, and political institutions as well as administrative structures are far from functioning well. Whether democratically elected as in Ghana, or rather authoritarian as in Burkina Faso, national governments usually have to be careful to not overly confront rural constituencies with controversial policies, as they constitute an important factor in the often fragile balance of power of developing states.

All these factors combined make it extremely unlikely that virtual water trade becomes a means of water governance that will have a considerable influence on agricultural production patterns in the Volta basin and beyond. If promoted by international agencies it might attract some degree of rhetorical commitment, but that it will find widespread implementation has to be doubted.

\section{Discussion}

By describing socio-economic, cultural and political conditions within the Volta basin we uncovered the constraints for the implementation of virtual water trade as a policy option. We also identified the main risks and uncertainties for the overwhelmingly rural population if a useful analytical tool were to turn into another transnational policy paradigm in order to save the worlds' water resources. What has not yet been addressed is an objection that evolves from a more theoretical perception, taking the specific agenda of global water institutions into focus. In his Water Forum Contribution article, Merrett (2003b) brings into question whether new water resources management strategies that are adjusted to the necessities of the free market can be the right measures to prevent global water stress. The main pillar of his argument is the fact that the World Water Forum in Kyoto has incorporated economic considerations into the international water debate and thus strengthened the role of private companies and international institutions, like the International Monetary Fund and the World Bank, in the development of new water management strategies.

Under the auspices of the World Bank, many developing countries indeed underwent neoliberal reforms in the water and agricultural sector. Problems of implementation have expectedly emerged because macro-economic considerations as well as administrative and legal arrangements did not fit all the diverse local practices and pluralistic legal understandings. From our point of view, this gap depicts 
one significant reason why seven years after the United Nations Millennium Summit, the expressed goals have moved increasingly to a distant prospect.

The experiences in and feedback from different countries in Asia, Latin America and Africa indicate that global water policies have only a restricted chance of success because, although stressed in theory, they lack democratic legitimacy in practice - an argument that has been outlined within the international debate about transnational policy networks and global governance (Hartmann, 2004; Nölke, 2004; Stone, 2004). The critical discussion has revitalized interesting views on the influence and performance of these networks and has made people aware of some of the latent aspects (spread of norms, values and knowledge) of policy transfer. Although virtual water trade can certainly not be considered as a policy in itself, it is nevertheless a concept that pushes these soft forms of transfer forward and therefore may lead to policy advice that may yet be taken by dominant players within the global water and food market.

What is problematic is the fact that the focus on water productivity and food trade introduces a logic that is entirely driven by hydrological and economic considerations at the macro level, whilst ignoring simple economic facts such as the lack of processing industries and market access for alternative products. As long as local resources and capacities for an economic transformation are lacking and unfair terms of international trade persist, it seems almost cynical to advocate virtual water trade. Better terms of trade rather than virtual water trade would enable many countries of the South to reduce levels of production, to engage in the processing of goods and thus save water. Taking a macro perspective by focussing solely on varying water use efficiency in different countries, the proponents of virtual water trade apply comparative advantage arguments to the water sector and some even portray the concept as an effective political strategy, as "serious local water shortages can be very effectively ameliorated by global economic processes" (Turton et al., 2003). Focussing on macro-ecological and macro-economic rationalities, they repeat some of the pitfalls that have been associated with the theory of comparative advantages. The approach is based on unrealistic assumptions, glosses over important economic, social, cultural and political boundary conditions and assigns a limited concept of unilinear development (Kößler, 1998). Standardized models of modernization according to the basic principle "one size fits all", fail the various living conditions of many target groups. Especially in poor developing countries, where major parts of the population depend on small-scale agriculture, the application of virtual water trade as a policy option would be rather harmful and create new patterns of poverty and dependency (Kluge \& Liehr, 2005; Youkhana \& Laube, 2006).

Furthermore, the focus on water footprints and water use efficiency ignores the way in which local farming and livestock systems are adapted to water scarce environments and overlook the seasonal nature of precipitation and agricultural production. Local production systems are therefore often falsely discredited when looked at under a macro perspective. Again, it was Merrett (2003a) who tried to caution us that if "one approaches agriculture from the perspective of water resources... a more rounded vision is lacking, one that understands that the water theme is only one amongst many, such as soil characteristics, land rights, labour skills, pest control, farm budgets and production patterns". Regionally and locally adapted water management strategies, like the set up of water storages (small reservoirs), the increasing use of shallow ground water and rainwater harvesting as measures to avoid water scarcity have more chances of success than an imposed assignment of self-sustaining food production. There are several cases from Asia and Africa for successfully introduced local solutions.

The displayed evolutionary-functionalist perspective on change and modernization was criticized by many social scientists (Kößler, 1998; Eisenstadt, 2000) because it has failed to address alternative perceptions of development. The abiding position of development agents and modernization theorists impedes the adoption of local solutions and paves the way for further top-down approaches. There are 
ample examples of failed top-down development and resource management strategies, for instance of the counterproductive implementation of land reforms (Deininger \& Binswanger, 2001; Benjaminsen \& Lund, 2002) and water sector professionals should try to learn from them.

\section{Conclusion}

It has been shown that the concept of 'virtual water trade' is derived from the macro-analysis of water productivity in agriculture and animal husbandry. The analysis of (international) food flows lacks the potential to be a widely implemented instrument for water governance, especially in countries where adjustment programs have led to the reduction of the state's role in the supervision of market forces. Nevertheless, the heuristic value of the analysis of virtual water flows is not disputed, and the debate has certainly opened interesting vistas on the seemingly irrational wastage of precious water resources in water-scarce regions by interrelating water, food and trade factors. The virtual water trade debate has also raised awareness of the potentials for international conflicts in water scarce regions, like the MENA region.

However, virtual water trade has not been proved to be a useful strategy to avoid water conflicts. This is not just because water conflicts mainly occur at a local level, but also because many factors like poor infrastructure, bad management and other social and political reasons cause conflicts over water, rather than just water scarcity itself (Youkhana \& Laube, 2006).

Using the example of agricultural production in the semi-arid Volta basin we could furthermore show that locally adapted production patterns that make use of (regional) comparative advantages, for example the cultivation of vegetables in the dry North while the rains in the South prohibit vegetable production, which grant production and marketing advantages, are falsely discredited. It shows that the virtual water trade approach ignores important cultural, market and politico-institutional factors that strongly affect the socio-economic realities of the regions. Using examples from the Volta basin, it could be shown that these neglected factors are actually the ones which drive economic development and policy processes. It seems naïve at best, and dangerous at worst, to believe that 'virtual water trade' could become a strategy of water governance; naïve because cultural, economic and political factors seem to preclude the widespread application of hydrological rationality in the design of economic policies; dangerous because 'virtual water trade', if promoted as water governance policy by international donors and policymakers, may become just another well-meaning but failed attempt to 'rationally' manage resources, which may nevertheless have potentially disastrous effects on the livelihoods of rural populations.

\section{References}

Agbodeka, F. (1992). An Economic History of Ghana, From the Earliest Times. Ghana University Press, Accra.

Allan, J. A. (1995). Water deficits and management options in arid regions with special reference to the Middle East and North Africa. In Water Resources Management in Arid Countries. Ministry of Water Resources, Muscat, Oman, pp. 1-8.

Allan, J. A. (2001). The Middle East Water Question: Hydropolitics and the Global Economy. I B Tauris, London.

Andah, W. \& Gichuki, F. (2003). Volta Basin Profile: Strategic Research for Enhancing Agricultural Water Productivity (Draft). International Water Management Institute, Challenge Program on Water and Food, Accra.

Applegren, B. (2004). Water and Ethics; Water in Agriculture. Series on Water and Ethics. Essay 5. UNESCO. Available at: http://unesdoc.unesco.org/images/0013/001363/136354e.pdf

Bates, R. H. (1981). Markets and States in Tropical Africa. University of California Press, Berkley. 
Benjaminsen, T. A. \& Lund, C. (2002). Formalisation and Informalisation of land and water rights in Africa: an introduction. The European Journal of Development Studies, 14(2), 1-10.

Berry, S. (1993). No Condition is Permanent: The Social Dynamics of Agrarian Change in Sub-Saharan Africa. University of Wisconsin Press, Madison.

Bradford, S. (2003). Paying the price: final goods protection in OECD countries. The Review of Economics and Statistics, 85(1), 24-37.

Caritas \& CIDSE (2004). Unfair trade and cotton. Global challenges-local challenges. A Caritas-CIDSE Report.

Chapagain, A. K. \& Hoekstra, A. Y. (2004). Water footprint of nations. Volume 1: Main report. UNESCO-IHE Research report Series No. 16, Delft, Netherlands.

Chapagain, A. K., Hoekstra, A. Y. \& Savenije, H. H. G. (2005). Saving Water through Global Trade. Value of Water Research Report Series. Vol. 17. UNESCO-IHE, Delft.

Christian Aid (2002a). A level playing field? Rice farming in Ghana. http://www.christian-aid.org.uk/campaign/trade/stories/ ghana1.pdf

Christian Aid (2002b). A rotten trade. Ghana's tomato farmers face unfair EU competition. http://www.christian-aid.org.uk/ campaign/trade/stories/ghana2.pdf

Deininger, K. \& Binswanger, H. (2001). The evolution of the World Bank's land policy. In Access To Land, Rural Poverty and Public Action. de Janvry, A. (ed.). Oxford University Press, Oxford, Chapter 17.

EIA (2003). Economic Community of West African States (ECOWAS). http://www.eia.doe.gov/cabs/ecowas.html

Eisenstadt, S. N. (2000). Multiple Modernities. Transaction Publishers, London.

FAO (2006). FAOSTAT data. http://faostat.fao.org

Government of Ghana (1995). Ghana-Vision 2020: The First Step 1996-2000. Assembly Press, Accra.

Hartmann, E. (2004). Die Rolle von internationalen Wissensnetzwerken in der transnationalen Entwicklungspolitik. In Peripherie und Globalisierter Kapitalismus: Zur Kritik der Entwicklungstheorie. Gerlach, O., Kalmring, St., Kumitz, D. \& Nowak, A. (eds). Brandes \& Apsel, Frankfurt a.M., pp. 263-294.

Hoekstra, A. Y. \& Hung, P. Q. (2002). Virtual Water Trade. A quantification of virtual water flows between nations in relation to international crop trade. Value of Water Research Report Series No. 11. http://www.unesco-ihe.org/Project-activities/ Project-database/Virtual-Water-Trade-Research-Programme/Hoekstra-A.Y.-Hung-P.Q.-2002-.-Virtual-water-trade-Aquantification-of-virtual-water-flows-between-nations-in-relation-to-international-crop-trade-Value-of-Water-ResearchSeries-No.-11-UNESCO-IHE

IMF (2006). IMF Fact Sheet April 2006. http://www.imf.org/external/np/exr/facts/hipc.htm

International Cocoa Organization (2005). ICCO Annual report 2003/2004. http://www.icco.org/anrep/anrep0304english.pdf

Kasanga, K. \& Avis, M. (1988). Internal Migration and Urbanization in Developing Countries. Findings from a Study in Ghana. University of Reading, Department of Land Management and Development, Reading.

Kempf, S. (2005). The Economic Community of West African States (ECOWAS). http://www.weltpolitik.net/print/2341.html

Kluge, T. \& Liehr, S. (2005). Anpassungsmodalitäten, Regionalisierung und Skalenübergänge im Konzept des virtuellen Wasserhandels: Expertenstatement im Rahmen des BMZ-Projekts. In Virtueller Wasserhandel_Ein realistisches Konzept zum Umgang mit Wasserarmut in Entwicklungsländern? Deutsches Institut für Entwicklungspolitik, Bonn.

Kößler, R. (1998). Entwicklung. Westfälisches Dampfboot, Münster.

Konings, P. (1986). The State and Rural Class Formation in Ghana: A Comparative Analysis. Kegan Paul International, London. Kranjac-Berisavljevic, G., Blench, R., Bayorbor, T. B., Turton, C. N., Abdulai, A. S., Boyed, C., Obeng, F. \& Drake, E. (1999). Rethinking Natural Resource Degradation in Semi-Arid Sub-Saharan Africa: The Case of Semi-Arid Ghana. Overseas Development Institute, London, and Faculty of Agriculture, UDS, Tamale, Ghana. http://www.odi.org.uk/RPEG/ soil_degradation/ghlit.pdf

Kunstmann, H. \& Jung, G. (2003). Investigation of Feedback Mechanisms Between Soil Moisture, Land Use and Precipitation in West Africa. IAHS publication 280: Water Resources Systems-Water Availability and Global Change. IAHS, Wallingford, pp. 149-159.

Laube, W. \& van de Giesen, N. (2006). Ghanaian water law and policy: institutional and hydrological perspectives. In Hydrological Information in Water Law and Policy: Current Practices and Future Potential. Wallace, J. S., Wouters, P. \& Pazvakavambwa, S. (eds). Kluwer, Dordrecht.

Lemarchand, R. (1989). African peasantries, reciprocity and the market: the economy of affection reconsidered. Cahiers d'Études Africaines, 29(1), 33-67. 
Merrett, S. (2003a). Virtual water and Occam's razor. Water International, 28(1), 103-105.

Merrett, S. (2003b). Virtual water and the Kyoto consensus. A water forum contribution. Water International, 28(4), 540-542. Migdal, J. S. (1988). Strong Societies and Weak States. State Society Relations and State Capabilities in the Third World. Princeton University Press, Princeton.

Ministry of Works and Housing (MoWH) (1998). Ghana's Water Resources: Management Challenges and Opportunities. Ministry of Works and Housing, Accra.

Nölke, A. (2004). Limits to democratic network governance: The case of transnational politics. Paper prepared for the Conference on Democratic Governance, Copenhagen 2004. http://www.ruc.dk/upload/application/pdf/2faadcbf/ AndreasNoelke_paper.pdf

Rodgers, C., van de Giesen, N., Laube, W., Vlek, P. L. G. \& Youkhana, E. (2006). The GLOWA Volta project: a framework for water resources decision-making and scientific capacity building in a transnational West African Basin. Water Resources Management, 21, 295-313.

Scott, J. C. (1985). Weapons of the Weak. Everyday Forms of Peasant Resistance. Yale University Press, New Haven \& London.

Stone, D. (2004). Transfer agents and global networks in the 'transnationalisation' of policy. Journal of European Public Policy, 11(3), 545-566, June 2004.

Turton, A. R. (2000). Precipitation, people, pipelines and power: towards a political ecology discourse of water in Southern Africa. In Political Ecology: Science, Myth and Power. Stott, P. \& Sullivan, S. (eds). Edward Arnold, London, pp. $132-153$.

Turton, A. R., Nicol, A. \& Alan, J. A. (2003). Policy Options for Water Stressed States: Emerging Lessons From the Middle East and Southern Africa. African Water Issues Research Unit \& Overseas Development Institute, Pretoria \& London.

UNDP (2003). Human Development Indicators 2003. http://hdr.undp.org/reports/global/2003/indicator/cty_f_BFA.html

Van Edig, A. (2002). Konflikte um Wasser -Wasserverfügbarkeit und Wassernutzung. Reiter, E. (ed.). Jahrbuch für internationale Sicherheitspolitik 2000, Hamburg, pp. 141-162.

von Benda-Beckmann, F. \& van der Velde, M. (1992). Laws As a Resource in Agrarian Struggles. Wageningen Agriculture University, Wageningen.

Wiggins, S. (1999). Setting the scene: recent change in West African farming and natural resource management. In Natural Resource Management in Ghana and its Socio- Economic Context. Roger, Blench (ed.). Overseas Development Institute, London, pp. 1-20.

World Bank Group (2004). World Development Indicators, 2004. World Bank Publications, Washington, DC.

World Fact Book (2006). Country Report: Ghana and Burkina Faso. http://www.cia.gov/cia/publications/factbook/

WTO (2001). Proposal by Burkina Faso on the negotiations on agriculture. Committee on Agriculture Special Session.

Youkhana, E. \& Laube, W. (2006). Virtueller Wasserhandel und Konflikte um Wasser: Expertenstatement im Rahmen des BMZ-Projekts. In Virtueller Wasserhandel-Ein realistisches Konzept zum Umgang mit Wasserarmut in Entwicklungsländern? Deutsches Institut für Entwicklungspolitik, Bonn. 